\title{
„Prosvijećena“ modernizacija i tolerancija u Habsburškoj Monarhiji u 18. stoljeću: problemi pristupa - konfliktni koncepti i kontradiktorne prakse ${ }^{1}$
}

\author{
Prethodno priopćenje \\ Preliminary communication
}

UDK 141.132(436-89)“17“

\begin{abstract}
Vjerska trpeljivost u Habsburškoj Monarhiji u 18. stoljeću, točnije, u reformskom razdoblju u drugoj polovici vijeka, dijeljeno je iskustvo epohe europske Prosvijećenosti. Utemeljena je u kritičkom propitivanju različitih shvaćanja trpeljivosti u rasponu od Voltairea i Rousseaua do Febroniusa i Muratorija. Njezina su povijesna izvorišta dublja. Monoteistički eklezijalni i monarhijski univerzalizam od 15 . do 17 . stoljeća iscrpljuju se u dugotrajnim cikličkim konfliktima s više europskih epicentara pa u 18. stoljeću ključnim postaje pitanje kako konfesionalne aspekte trpeljivosti povezati sa sekularnim imperativima slobode savjesti. S vremenom je vjerska trpeljivost za prosvjetitelje sve manje interkonfesionalni, a sve više intrakonfesionalni problem s etičkim i političkim implikacijama. Za prosvijećene apsolutiste, poput Habsburgovaca u to doba, bitni su njezini sekularni aspekti. Ključno je pitanje kako osigurati mir i boljitak u društvu. Radilo se o tome da se religiju svede na "društvenu činjenicu“ (un fait social), podložnu načelu korisnosti ili na superstrukturu koja legitimira i reprezentira materijalne interese društva. $U$ oba je slučaja religijska tolerancija postajala i sekularni fenomen.
\end{abstract}

Ključne riječi: Habsburška Monarhija, Habsburgovci, 18. stoljeće, prosvjetiteljstvo, kameralizam, vjerska trpeljivost

V oltaire u Filozofskom rječniku, jednome od svojih „najzrelijih filozofskih djela“ (D. Grlić 1982: 436), zaključujući natuknicu o toleranciji (u prvom izdanju) - nakon mnoštva nesmiljenih kritičkih opservacija o kršćanskoj intoleranciji od apostolskih vremena do njegove suvremenosti - u jednom dahu zapisuje: „Vidite Sultana: on upravlja gebrima, banijancima, grčkim hrišćanima, nestorijancima, rimokatolicima. Prvi koji pokuša da stvara nered bude nabijen na kolac, i svi su mirni“ (Voltaire 2009: 334). Da nam nisu poznati njegova Rasprava o

Članak je nastao kao dio istraživanja vjerske povijesti u znanstvenom projektu „Triplex Confinium: hrvatska višegraničja u euromediteranskom kontekstu“. 
toleranciji i brojne druge formulacije shvaćanja istog pojma, mogli bismo pogrešno zaključiti da Voltaire zagovara "sultansko“ shvaćanje tolerancije u 18. stoljeću. ${ }^{2}$

Rousseau, sa svoje strane, pišući o „građanskoj religiji“ u $O$ društvenom ugovoru..., odrješit je već u prvoj rečenici: „Čim lj(udi) žive u društvu, treba im religija koja ih održava (LVI). Nikada narod nije postojao niti će postojati bez religije i ako mu je nikako ne damo, stvorit će je sam od sebe ili će biti žrtvovan“ (Rousseau 1993: 98). Napraviviši razliku između „religije čovjeka“ $i$,,religije građanina“, svoju pažnju usredotočuje na potonju: „Druga je dobra u tome što sjedinjuje božanski kult i ljubav prema zakonima i što čineći od domovine predmet obožavanja građana, ona ih uči da služiti državi znači služiti bogu“ (Rousseau 1993: 98). Svjestan je teškoća koje proistječu iz ovakva shvaćanja „religije građana“: „Ona (tj. „religija građana" - [opaska autora]) je nadalje loša kada, postajući isključivom i tiranskom, čini narod krvoločnim i netolerantnim tako da odiše samo strahotom i pokoljem te misli da čini sveto djelo ubije li svakoga tko ne prihvaća njezine bogove i njezine zakone. Nije dopušteno (sic!) svezati čvor pojedinačnoga društva na uštrb ostatka ljudskog roda" (Rousseau 1993: 99). On ne pronalazi rješenje za problem koji je otvorio, ali ne izbjegava kategoričke imperative: „...moramo tolerirati sve one koj(i) toleriraju druge, samo ako njihove dogme nemaju ništa suprotno dužnostima građanina. Ali tkogod kaže: izvan crkve nema spasenja, mora biti otjeran iz države, osim ako je država crkva" (Rousseau 1993: 103). Zamijenimo li uvjetno pojam "država“ pojmom "vladar", naći ćemo se u Voltaireovu "sultanskom" krugu. Njegova Razmatranja o vladavini u Poljskoj i o njezinoj namjeravanoj reformi sadržavaju ne samo brojne formulacije koje praktičnopolitički nužno reproduciraju ionako teške konflikte s Prusijom i Rusijom, nego i takve koje Poljaci njegova doba nikako ne mogu prihvatiti, odričući se teritorija pretežno naseljenih poljskim akatoličkim podanicima: „Počnite od toga što ćete suziti svoje granice, ako hoćete reformirati svoju vladavinu“ (Rousseau 1993: 171). Dakle, „društveni ugovor“ je to uspješniji što je politička zajednica više monokonfesionalna, dakako, na Rousseauovim političkim pretpostavkama (Rostworowski 1990: 69-89). Rousseau u biti nema rješenja za probleme koji proistječu iz multikonfesionalnosti poljske države, a koji su u konkretnom slučaju u vezi s činjenicom da su brojni poljski podanici pravoslavni i protestanti.

Polazeći od nemogućnosti areligijske političke zajednice, Voltaire i Rousseau, svaki na svoj način, moraju se suočiti s pitanjem o implikacijama religijskog i napose konfesionalnog pluralizma. Oni ga u biti samo etički razrješuju. U „Molitvi Bogu“ u Raspravi o toleranciji, Voltaire kaže: „Ne obraćam se stoga više ljudima; obraćam se tebi, Bože svih bića, svih svjetova i svih vremena: (...) Nisi nam dao srce da se mrzimo i ruke da ubijamo; učini da pomognemo jedni drugima podnositi teret mučnog i prolaznog života;..." (Voltaire 1988: 122). ${ }^{3}$ Zaključni obrat je etički imperativ: „Vrlina nije dobro, to je dužnost; i ona je različite vrste, nekog višeg reda“, ističe Voltaire (Voltaire 2009: 99). Isti problem rješava i Rousseau, a neupitna je samo njegova savršeno jasno izrečena dijagnoza: „Oni koji razlikuju građansku netoleranciju od crkvene netolerancije griješe. Jedna nužno vodi drugoj, te dvije netolerancije su neodvojive. Nemoguće je živjeti u miru s ljudima koje smatramo prokletima" (Rousseau 1993: 102). Temeljni problem vjerske trpeljivosti za prosvjetitelje nije interkonfesionalne

\footnotetext{
O ambivalencijama Voltaireova odnosa prema islamu i Osmanskom Carstvu, vidjeti: Hišam Džait, Evropa i islam (Sarajevo $1989^{2}$.), a posebno potpoglavlje „Francuski intelektualci i islam. 1. Filozofi prosvjetiteljstva: Voltaire i Volney" (str. 27-34).

3 Stoga dekristijanizacija revolucionarne Francuske kreće u smjeru sekularizacije religijskog izazova. Neuspjeh dekristijanizacije, pak, vodi k „imperijalnoj katoličkoj obnovi“, kao i sklapanju konkordata pod carskim uvjetima, odnosno - pored ostalog - mnoštvu akata o vjerskoj trpeljivosti prema akatolicima. Američka revolucija, nasuprot tome, konstitucionalno jamči individualne građanske vjerske slobode, „dekonfesionalizirajući“ na taj način projekt američke nacije, a istovremeno otvarajući skoro neograničene mogućnosti razvoja religijskog pluralizma (Jefferson 1984., uputnica „Religious freedom“).
} 
nego intrakonfesionalne naravi. Isusovački gojenac François-Marie Arouet, tj. Voltaire, postavlja ga u dugome povijesnom trajanju: „Sveti Toma je toliko iskren da priznaje da hrišćani nisu zbacili careve s prestola samo zato što nisu mogli. Njihovo mišljenje je bilo da ceo svet mora biti hrišćanski. Prema tome, oni su obavezno bili neprijatelji celog sveta, dok nije preobraćen" (Voltaire 2009: 333). U evangelizaciji svijeta, naglašava Voltaire, kršćani se ne prestaju međusobno sporiti i osporavati: „Oni su međusobno bili neprijatelji jedni drugima u svim spornim stvarima. (...)...i od toga vremena sve do danas hrišćanska crkva kupa se u krvi“ (Voltaire 2009: 333). U tome je za Voltairea ključna razlika između židovskog i kršćanskog monoteizma: „Jevreji su poštovali svog Boga; ali nikada se nisu čudili što svaki narod ima svoga" (Voltaire 2009: 333). ${ }^{5}$

Previđajući na tom mjestu različite mogućnosti čitanja Starog zavjeta, kao i različite reference na židovsku povijest, Voltaire, kao i drugi prosvjetitelji u 18. stoljeću, previđaju i učinak dugotrajne „tranzicije“ iz „politeističkih" u „monoteističke“ religije, iz kulturnih religija u religije Knjige, iz kulturno limitiranih religija u univerzalne religije, odnosno, iz „primarnih" u "sekundarne“ religije, iz religija sinkretičkih akulturacija u religije antagonističkih akulturacija, dakle, probleme koji nisu u vezi samo s poviješću kršćanstva (Assmann 2004: 7-8). ${ }^{6}$ Spomenutom „tranzicijom“ uspostavljaju se konkurentni, međusobno isključivi odnosi između „istinskih" i "lažnih" vjera, i to sinkrono s konstituiranjem teritorijalnih političkih zajednica, dakle, takvih koje se prije ili kasnije neizbježno suočavaju s izazovom univerzalnog religijskog legitimiteta. Jedne i druge institucionaliziraju se kao vlasti, tj. kako duhovne, tako i svjetovne. Neovisno o tome u kakvim su kada sve mogućim odnosima te kako se sve očituju prema svojim sljedbenicima i onima koji to nisu, odnosno, prema svojim podanicima i onima koji to nisu, duhovno sljedbeništvo i svjetovno podaništvo u europskom "starom poretku“, eklezijalni i monarhijski univerzalizam iscrpljuju se u dugotrajnim cikličkim konfliktima s više europskih epicentara od 15. do 17. stoljeća.

Neovisno o različitim mogućnostima „čitanja“ modernih shvaćanja tolerancije, neupitno je da su ona od 1555. i/ili 1598. prije političke nego moralne ili vjerske naravi, ako ni zbog čega drugog onda zato što je riječ o zakonskim odredbama i uredbama nastalima s ciljem da osiguraju mir u društvu (Barlow 1999: 11). Rasprava o toleranciji time je u biti sastavni dio ograničavanja crkvenog utjecaja, što čak i Gabriela Marcela navodi na zaključak da je tolerancija u tom smislu prije svega jedna "contre-intolérance“ (Barlow 1999: 12). Međutim, Nanteski edikt, osim što je „pakt o nenapadanju“, nema nikakva utjecaja na interkonfesionalno približavanje u Francuskoj. Čak ni Erazmo ili Montaigne, kao ni bilo tko od velikih protestantskih reformista nisu „tolerantni“ u smislu u kojem se danas koristi taj pojam (Barlow 1999: 21). ${ }^{7}$

Rješenje kršćanskih međusobica ponovno je u etički utemeljenoj toleranciji: „Ova strašna nesloga koja traje već toliko vekova, velika je pouka kako treba međusobno da praštamo greške koje činimo; nesloga je veliko zlo ljudskog roda, a trpeljivost joj je jedini lek" (Voltaire 2009: 336).

5 Vidjeti oprečni pristup katoličkoj tradiciji tolerancije: «Religious Toleration» i «History of Toleration» u: Catholic Encyclopaedia http://www.newadvent.org/cathen/14763a.htm (30. listopada 2011., 0:41).

Vidjeti, također: Jan Assmann, Monoteizam i jezik nasilja, Beograd 2009.

U 16. stoljeću pojam tolérer još je uvijek jako obilježen svojom latinskom etimologijom: tolerare je porter (nositi). Indoeuropski korijen nalazi se $u$ imenu grčkog diva Atlasa koji na svojim ramenima nosi svijet. $U$ klasičnom latinskom tolerare dobiva i značenje supporter (podnositi), endurer (trpjeti) nešto što je više ili manje neugodno. U 18. stoljeću l'intolérance za francuske filozofe postaje simbol tiranije, odbijanja rasprave, ograničene i priglupe autoritarnosti, odnosno, neprijatelj slobode. Nasuprot tome, la tolérance stječe nove vrline, iako nesretni glagol tolérer češće ima pasivna (supporter avec constance, ustrajno podnositi) nego aktivna značenja (faire preuve de compréhension et d'ouverture, dokazati razumijevanje i otvorenost) (Barlow 1999: 22, 23). 
Bitka za modernu toleranciju prije svega je urbani fenomen. U urbanom prostoru (urbs), koji je i zajednica vjernika (ecclesia) i zajednica građana (civitas), kultura vjerske trpeljivosti egzogene je naravi, a za njezino su održanje i urbanu interiorizaciju presudni autoritet nadređene vlasti $i$, nadasve, prednosti i korist koji se njezinim prakticiranjem stječu. Takav je jedan primjer potkraj 16. stoljeću Livorno, koji Medici pretvaraju od malog primorskog grada u veliki porto franco, pozivajući trgovce iz „cijelog svijeta“ da se u njemu slobodno nastane i posluju, neovisno o vjeri. Novo stanje postaje neupitnim kada ga instituiraju i kada za njega postanu odgovorne gradske vlasti (Do Pacq et al. 2010: 19, 21). Kada se religiju svede na "društvenu činjenicu“ (un fait social), podložnu načelu korisnosti ili na superstrukturu koja legitimira i predstavlja materijalne interese društva, religijska tolerancija postaje i sekularni fenomen (Do Pacq et al. 2010: 11). Religijska convivenza stječe unutrašnju urbanu logiku, i to po mjeri njezinih aktera, njihovim praksama i razlozima koji in lokalno motiviraju, a to je proces u kojem se reflektira autonomija političkog razuma (Do Pacq et al. 2010: 15). Međutim, religijska convivenza nije cilj po sebi, jer ona oscilira između netrpeljivosti i ravnodušja koje ju nadilazi, omogućujući akterima da djeluju ne pitajući se o identitetu „drugoga“ (Do Pacq et al. 2010: 17). Time je religijska convivenza oblik aproprijacije urbanog prostora (Löw 2001).

Vjerske "obnove" od 16. do 18. stoljeća, dakle, više nisu u konfesionalnom singularu. Rimokatolička je $s$ jedne strane najveća gubitnica, ali je $s$ druge i najveća dobitnica, napose zbog globalne ekspanzije rimokatoličanstva. Međutim, ustrajne protestantske "obnove" od 16. do 18. stoljeća s prepoznatljivim teritorijalno-političkim težištima, dugotrajni osmanskoislamski pritisak na jugoistočnu, srednju i istočnu Europu od 14. do 18. stoljeća te "povratak“ pravoslavlja u Europu u europeiziranoj ruskoj imperijalnoj „obnovi“, ograničuju učinke brojnih inačica „,konfesionalnog discipliniranja“. ${ }^{\circ}$ Otvaraju se brojne mogućnosti sekularnoga, filozofijsko-teologijskog, ali i, prvi put u europskoj povijesti, kulturnog, političkog te ekonomskog rekonceptualiziranja Europe u svjetskom obzorju. Zajednički je nazivnik svih tih rekonceptualizacija „antropocentrički obrat“, koji, neovisno o svim mogućim izvođenjima, ima božansko ishodište i uporište, ali, sve učestalije, racionalističku argumentaciju: „Cette nouvelle conception de la foi repose sur deux arguments: Dieu a donné la raison à l'homme pour qu'il puisse se sauver par la connaissance et il est possible de connaître les vérités les plus importantes du christianisme par la méditation de la parole du Dieu sans qu'il soit nécessaire de passer par la médiation d'une Église; la conscience a des droits inviolables, même lorsqu'elle se trompe et s'égare c'est un crime de l'outrager, et Dieu punira plus sévèrement l'injustice que l'erreur" (Delon 1997: 1049).

\footnotetext{
„Lončići su bili pomiješani“ već u 16. stoljeću: „François I'r, très chrétien, s’unira avec les musulmans, contre Charles Quint, très catholique. François I Ir donnera de l'argent aux lutériens d'Allemagne, pour les soutenir dans leur révolte contre l'empereur; mais il commencera selon l'usage, par faire brûler les lutériens chez lui“" (Delon 1997: 1049-1050. Citat iz Voltaireova Dictionnaire philosophique). Tome prethode, a i slijede, projekti „vjerskog mira“, dijelom „endogene“, a dijelom „egzogene“ europske naravi. Među njima se ističe onaj Cusanov De pace fidei: „Il concetto di pace della fede di Cusano, svolto nella celebre opera De pace fidei, redatta nel 1453 sotto lo choc dell'avanzata dei Musulmani turchi e la caduta di Constantinopoli, non ci pare riconducibile ad alcuno dei più comuni concetti di tolleranza oggi accettati: dal concetto generale, con cui si indica la coesistenza pacifica tra confessioni diverse e il loro reciproco riconoscimento, a quello dell'affermazione delle libertà di coscienza individuali del cosidetto, libertinismo spirituale', fino a quello di alcuni pensatori dell'illuminismo, che intereso per tolleranza la reciproca sopportazione delle diverse debolezze umane, per giungere alla libertà religiosa e alla religione della libertà dei primi filosofi del Novecento italiano su fondamento politico e giuridico come nell'opera del Ruffini“ (Graziella Federici Vescovini, "L'irenismo di Nicolò Cusano“, u: Sina (a cura di) 1991: 27-28). Mnogo je poznatiji s time u vezi Erazmo Roterdamski, koji je ne samo danas jedan od najcjenjenijih modernih humanista, nego i svojevrsni simbol europske humanističke tradicije uopće, napose zbog svog shvaćanja i prakticiranja tolerancije u dobu intolerantnih.
} 
Onog trenutka kada se dođe do spoznaje da je nepravda prema drugom čovjeku veći grijeh nego vjeroispovijedna zabluda, poimanja trpeljivosti dobit će značenja koja će daleko prelaziti granice duhovno/svjetovnog dualizma i postat će nerazlučiv dio ponajprije prirodnopravnih shvaćanja temeljnih prava čovjeka i građanina, odnosno, povijesno alternativnog shvaćanja konstitucionalizma, šire, političke kulture. ${ }^{9}$

Važno je istaknuti da odlučujuće doprinose modernom shvaćanju tolerancije daju ljudi koji su po svojim osobnostima međusobno vrlo različiti, ali ih, pored ostalog, povezuje činjenica da intelektualno „angažirano“ reagiraju na kršenje vjerskih prava koja ugrožavaju moderno shvaćena ljudska i građanska prava (npr., Baruch Spinoza vs. židovsko pravovjerje, John Locke vs. Clarendon Code, Pierre Bayle vs. katolička i protestantska hipokrizija, Voltaire u slučaju Calas itd., itd.). U Lockeovu slučaju, napose, uočljivo je da njegov empirizam nije limitiran na filozofsku refleksiju, nego utječe i na njegovo javno djelovanje. Kada je o shvaćanju tolerancije riječ, čemu daje fundamentalne doprinose u modernoj europskoj tradiciji, njegovi se stavovi s praktičnopolitičkog stajališta mogu razumjeti i kao reakcija na "Clarendon Code“, kojima se ranih 1660-ih u Engleskoj obnavlja i širi religijski monopol Anglikanske crkve, ograničuju vjerska prava svih onih koji nisu anglikanci, ali ih se isto tako isključuje iz javnih službi itd. (Vernon 2010: IX). Tim su veći i izazovi religijske tolerancije. U 18. stoljeću ona se već odnosi na vjerska (metafizička, etička) uvjerenja, vjerske akte (poput obreda i drugih akata kojima se posvjedočuje vjersko uvjerenje) i same inovjernike u iskazivanju njihovih vjerskih uvjerenja (Newman 1982: 7). Locke je jedan od najzaslužnijih za širenje polja tolerancije.

U njemačkoj tradiciji, bitnoj za razumijevanje habsburških aproprijacija prosvjetiteljskih shvaćanja tolerancije, u novije doba iznova se ističe da su ključni mislioci, kao Immanuel Kant, Georg W. F. Hegel i Friedrich Schleiermacher studenti protestantske teologije (Graf, u: Seligman (ur.) 2004: 106) ${ }^{10}$. Kant, primjerice, nastavlja kritiku "skripturalnog univerzalizma“ sa svim njegovim obrednim i drugim implikacijama, što "systematically prevent the human being from fulfilling the demands of the moral law and the entire realm of morality" (Erlewine 2010: 92). Kantov se projekt i sastoji u preoblikovanju prirode religije i Boga te isticanju etičkih vrijednosti univerzalne ljudske zajednice (Erlewine 2010: 29, 30). ${ }^{11}$ Budući da je čovjek u protestantskoj tradiciji „a notorious sinner", drugačije se postavlja i pitanje crkvene nepogrješivosti, što olakšava izvođenje modernog poimanja tolerancije s protestantskog stajališta. Drugim riječima, ako vjera može pomoći ljudima da razumiju sami sebe u "relativnim pojmovima“, ista ta vjera omogućit će im da se vide "skeptično" (Graf, u: Seligman (ur.) 2004: 108, 109)12 Graf, očito, predlaže novo čitanje čitave njemačke prosvjetiteljske tradicije, napose kada je riječ o toleranciji.

Pritom je bitno imati na umu da je glavna njemačka ideja ideja konfesionalnog pariteta. $U$ njoj je bit staroga njemačkog pravnog poretka, a s njime je u vezi ideja konsenzusa, koji je vrlo važan i u modernome njemačkom konstitucionalizmu, konstitucionalizmu države blagostanja. Međutim, to je nešto različito od tolerancije. Riječ je o prihvaćanju drugog, ne kao drugog nego

9 „De valeur religieuse la tolérance accède ainsi progressivement au rang de valeur politique, mais elle suppose alors la définition d'un champ autonome du politique qui peut lui assigner certaines limites" (Delon 1997: 1050).

10 Ponovljeni naglasak: „...the German Enlightenment, in spite of people like Mendelssohn and so on, has mainly been undertaken by German Protestant thinkers“ (Graf, u: Seligman (ur.) 2004: 107). Također: „....the autonomous self is something specifically Protestant" (Graf, u: Seligman (ur.) 2004: 108).

11 Iggers 1983; Grafova kritika njemačkog prosvjetiteljstva postmoderno je intonirana: „My first point would be that religious language is a language of fiction. (...) You can use the same symbols, words, or narratives to build extremely opposite or different cognitive maps. (...) On the one hand, you can create strong images of the self, of social groups or collective actors. All these "God is on our side“ theologies". (Graf, u: Seligman (ur.) 2004: 107).

12 S time u vezi Graf upozorava na važnost Popkina (Popkin 2003). 
u vezi s nekim praktičnim razlogom (Graf, u: Seligman (ur.) 2004: 108). Kultura tolerancije u njemačkom je slučaju vezana za kontekst dijeljenoga, zajedničkog povijesnog iskustva prema kojem se svi individualni činitelji suglašavaju ostaviti otvorenima probleme „krajnjih uzroka“ ili prepustiti ih akademskoj raspravi (Graf, u: Seligman (ur.) 2004: 108).

Fenomenologija moderne grupne tolerancije ima dva vida, tj. jedan kojim se očituje tolerancija prema onima koji su izvan grupe (npr., članovi drugih religijskih grupa) i drugi, kojim se iskazuje tolerancija prema članovima vlastite grupe koji su unutrašnji disidenti, heretici, odnosno, koji su devijantni u odnosu prema religijskim normama. Stvar je u tome da se srednjovjekovna tolerancija odnosi na grupne identitete, a moderna na pojedince i njihove postupke (Seligman (ur.) 2004: 139). Srednjovjekovno poimanje zajednice podrazumijeva zajednicu kao posjednicu istine. Time su i granice zajednice podudarne s granicama istine. U modernim je zajednicama pojedinac taj koji se suočava s neizvjesnostima traganja za istinom. Međutim, tolerancija je moguća samo s vrijednosnog stajališta (Graf, u: Seligman (ur.) 2004: 140, 141).

Stoljeće između Augsburškoga vjerskog mira (1555.) i Vestfalskog mirovnog ugovora (1648.) doba je katoličke rekonkviste i obnove u habsburškim nasljednim zemljama. One u tome doista nisu jedinstven slučaj u Europi, ali su jedinstvene po tome što se rekonkvista i obnova zbivaju sinkrono s krajnje neizvjesnim suočavanjem s osmansko-islamskim izazovom u srednjoj i jugoistočnoj Europi. ${ }^{13}$ Neizvjesnim što zbog osmanske moći, što zbog ambivalentnih savezništava s ugarske strane i same uveliko „inficirane“ protestantskim herezama! Otuda su habsburške katolička rekonkvista i obnova, s jedne strane, od vladara do vladara, iz jedne dinastičke generacije do druge, krajnje oscilatorne, odnosno, pragmatične u skladu $s$ imperativima dinastičkih interesa, a, s druge strane, u presudnim trenucima, nesmiljene $u$ skladu s načelima ecclesia militans, i to na antemurale Christianitatis - neovisno o tome je li riječ o vanjskim ili unutarnjim protivnicima. ${ }^{14}$ Dug je put u takvim uvjetima i do stabilnoga pravnog poretka u zemljama s mnoštvom povijesnih prava, a još duži do trpeljivosti među podanicima „opsjednutih“ konfesionalnih identiteta. ${ }^{15}$ Od Ferdinanda I. do Marije Terezije, dakle, dva i pol stoljeća, kada je o inovjernim podanicima riječ, ako ih se uopće trpjelo, najčešće se to činilo $\mathrm{s}$ ravnodušjem, točnije, s kalkuliranim ravnodušjem. Ravnodušja nestaje ako ima nade da će se „zabludjeli“ vratiti „jedinoj pravoj vjeri“. ${ }^{16}$ Bartonovi primjeri ipak zavode na „krivi put“.

Konfesionalni pluralizam u zemljama pod habsburškom vlašću, i to na imperijalnom višegraničju postojano limitira šanse bilo kojem konfesionalnom ekskluzivizmu. Pruski kralj Fridrik II. shvaća to prije Habsburgovaca, doduše, poslije Sedmograđana (1568.) i Poljaka (1655.), ali ne toliko ranije da Habsburgovci ne bi mogli prihvatiti multikonfesionalni izazov. To postaje moguće tek kada se Habsburgovci i na svojim istočnim i na svojim zapadnim granicama na izmaku 17. stoljeća iznova suočavaju s izazovima interkonfesionalizma. Pomicanjem granica dinastičke vlasti daleko na ratovima opustošeni Jugoistok, od Južne Ugarske do Galicije, inovjernici postaju poželjni privilegijalno tolerirani podanici tamo gdje istovjernih zadugo ne bi moglo biti. Tako je, pored ostalih, „riješeno“ pitanje austrijskih evangelika,

\footnotetext{
Salzburški evangelici raseljeni su između 1683. i 1733.

14 U posljednjim desetljećima 17. stoljeća inovjerci posvuda u Europi loše prolaze, od Ugarske do Francuske i Irske: „...1671-1681 kommt es zur Trauerdekade des ungarischen Protestantismus, 1685 zur Massenflucht der Reformierten aus Frankreich, 1695 zur Aufhebung der Glaubensfreiheit für die katholischen Irren, die nur vier Jahre lang praktiziert worden war, ..." (25).

15 Peter F. Barton, „Der lange Weg zur Toleranz“ (Barton (hrsg.), Im Lichte 1981: 11-32).

16 Marija Terezija, prema Bartonu, o moravskim evengelicima 1777.: „....in dem unglücklichen Religionsirrthum verfallene Unterthanen" (13). Josip II. bi u isto vrijeme isto tako sve dao za pokatoličavanje protestantskih podanika: „Ich würde alles hingeben, was ich besitze, wenn ich die Protestanten Ihrer Länder zu Katholiken machen könnte" (Josip II. Mariji Tereziji, 20. srpnja 1777., u: Barton 1981: 13-14, bilj. 13).
} 
a tako se na habsburškom tlu nalaze i brojni pravoslavni Srbi, a ove dvije zajednice nisu jedine. Imperijalna stabilizacija, koja mora biti isto tako gospodarska kao i pravnopolitička ili vojna, na prijelazu 17. u 18. stoljeće posvuda iziskuje aktivnu populacijsku politiku. Vodi je Prusija, ali je vodi i Rusija, obje konkurentske sile. $\mathrm{K}$ tome, protestantski nezadovoljnici pod habsburškom vlašću uvijek mogu pokušati prijeći u Prusiju, kao i pravoslavni u Rusiju, što, uostalom, nerijetko i čine. $S$ druge strane, neriješena pitanja u vezi sa statusom pravoslavnih podanika uvijek mogu izazvati Rusiju da se miješa u habsburške poslove, kao i Prusiju, kada je riječ o protestantima. Drugim riječima, čak i kada ne bi bilo nikakve volje za prosvijećenom modernizacijom na habsburškoj strani, geostrateški imperativi činili bi svoje.

Međutim, volja za dalekosežnim reformama u Habsburškoj Monarhiji itekako postoji i u prvoj i u drugoj polovici 18. stoljeća, a posebno sredinom stoljeća, u doba kada je Marija Terezija puna reformskog elana. Katolička obnova i imperijalna revitalizacija od 1740. do 1763. čine svoje i njezin je dvor stjecište intelektualnih elita u mnogim područjima znanja i umijeća. Ako ih osobno nema, njihove su knjige i, što je još važnije, njihovi su učenici tu gdje nastaje novi imperij na starim temeljima Svetoga Rimskog Carstva. Izlišno je spominjati njihova sada već dobro poznata imena. Važnije su njihove poruke i projekti, uključujući one koji se odnose na pitanje tolerancije: „Der Staat hat für alle Untertanen zu sorgen: Daraus ergibt sich die Pflicht der staatlichen Toleranz." (Puffendorff, u: Barton 1981: 29) Odatle do politike crkvenih reformi samo je jedan korak: „Der Herrscher hat für die Glückseligkeit seiner Untertanen zu sorgen, er kann, solange er das „Eigentliche“ nicht antastet, in die äußere Ordnung des Kirchentums bis hin in die gottesdienstlichen Zeremonien, ordnend eingreifen." (Christian August von Beck, u: Barton 1981: 30) Od njega potječe i stav koji je tako blizak protestantskim prosvjetiteljima: „Es ist eine reformatorische Erkenntnis, dass die Kirche im Spannungsfeld von Gottes Leistung, seiner gubernatio, und der Verwirrung der Menschen, ihrer confusio, existiert." (Barton 1981: 32) Odatle je već vrlo kratak put kojim prosvijećeni umovi poput Josipa II. shvaćaju kolika je „Schädlichkeit alles Gewissenszwanges“ (Lutz, u: Rendtorff 1982: 12).

Ipak, bitan je dinastički utilitarizam, koji nije uvijek prosvijećen, ali nastoji biti pragmatičan. Habsburška kameralistika („Oeconomische, Policey- und Cameral-Wissenschaft“) otvara mnogima dotad zatvorena vrata. Doista, „(i)t is true that religious toleration in Austria, as elsewhere in Europe, was brought about largely by non- or irreligious forces. (...) Joseph's ecclesiatical politics, like the rest of his statecraft, was secular but not secularistic. ...some historians argue that his policy of toleration was purely utilitarian..." (O'Brien 1969: 5).

Religijska kultura habsburške tolerancije također ne može biti zaobiđena. Josip II. nije vladar-mislilac, ali je vladar koji misli i asimilira utilitarne poticaje: „Both ultramontane and secularistic critics overlook the Edict's indebtness to the enlightened Catholic thought represented by the anti-curial Rhineland bishop, Johann Nikolaus von Hontheim, alias Febronius, and the erudite archivist of Modena in Italy, Lodovico Muratori“'(O'Brien 1969:5-6). Dakle, mijenja se i Rimokatolička crkva, kao što se dirigiranim državnim intervencionizmom reformiraju i druge crkve, odnosno, vjerske zajednice: "Concordia“ uključuje i „Toleranz" i „Kirchenreform" (Lutz, u: Rendtorff 1982: 26) u habsburškoj sekularnoj jurisdikciji. Srpsko pravoslavlje u Habsburškoj Monarhiji, primjerice, isto tako doživljava pomak od leopoldinske korporativno privilegijalne "Kirchen-Nation“ prema jozefinskoj individualnoj emancipaciji, duhovnoj i svjetovnoj. ${ }^{17}$ Analogne promjene zbivaju se i među protestantima i među Židovima pod habsburškom vlašću.

17 „...hat auch bei der Emanzipation der Orthodoxen nur die einzelnen Gläubigen ins Auge gefaßt, nicht wie ehedem Kaiser Leopold die „Kirchen-Nationen“ als Gesamtheit. Die Beschränkungen wurden aufgehoben, die es den Orthodoxen bisher verwehrten, in den Mittelstand, ins gehobene Bürgertum, in den Beamtenstand und ins Heer aufzustriegen“" (Barton 1981: 100). 
Na kraju, umjesto zaključka - važna napomena! Za razliku od protestantskih njemačkih teologa, katolički njemački teolog Sellmann, kojeg izdvajam među brojnima drugima, predlaže drugačije kritičko čitanje prosvjetiteljske tradicije, uključujući i poimanje tolerancije. ${ }^{18}$ Osporavajući racionalističku tezu o modernim društvima kao sekularnim, tj. društvima, u suštini, bez religijskih utjecaja (,in ihrem Kernbereich als religiös unbeeinflusste Gesellschaften"), Sellmann se oslanja na više suvremenih mislilaca koji omogućuju religijsko redefiniranje temeljnih problema moderne (José Casanova i „öffentlicher Religion“, Thomas Luckmann i „,religiöse Individualität“, Jürgen Habermas i „Post-Sekularität“, Hubert Knoblauch i „Entdifferenzierung von Religion und Kultur“, Rodney Stark i „Modernisierung der Religion“ itd.). Međutim, riječ je o „čitanjima“ ex post facto, koja su legitimna danas, kada je i pitanju suvremenost i koja tek posredno mogu biti poticajna za raspravu o problemima tolerancije u 18. stoljeću. Međutim, to je već druga tema.

\section{POPIS LITERATURE}

\section{ARNETH 1867}

Alfred R. v. Arneth, Maria Theresia und Joseph II., Ihre Correspondenz, 3 Bde, Wien 1867.

\section{ARNETH 1863-1879}

Alfred R. v. Arneth, Geschichte Maria Theresia's, 10 Bde, Wien 1863-1879.

\section{ASSMANN 2004}

Jan Assmann, Le prix du monothéisme, Paris 2004.

\section{BAER 2008}

Marc David Baer, Honored by the Glory of Islam. Conversion and Conquest in Ottoman Europe, Oxford University Press, 2008.

\section{BARLOW 1999}

Michael Barlow, Pour une théologie de la tolérance, Desclée de Brouwer, 1999.

\section{BARRES 1974}

Egon Barres, Das Vorurteil in Theorie und Wirklichkeit, Opladen 1974.

\section{BARTON 1978}

Peter F. Barton, Jesuiten, Jansenisten, Josephiner, Wien 1978.

\section{BARTON 1981}

Peter F. Barton, (ed.), Im Zeichen der Toleranz. Aufsätze zur Toleranzgesetzgebung des 18.
Jahrhunderts in den Reichen Joseph II., ihren Voraussetzungen und ihren Folgen. Eine Festschrift, Wien 1981.

\section{BARTON 1981}

Peter F. Barton (ed.), Im Lichte der Toleranz. Aufsätze zur Toleranzgesetzgebung des 18. Jahrhunderts in den Reichen Joseph II., ihren Voraussetzungen und ihren Folgen. Eine Festschrift, Wien 1981.

\section{BOBBIO - MATTEUCCI 1990}

Norberto Bobbio - Nicola Matteucci, Dizionario di politica, Torino 1990.

\section{CHARTIER 1989}

Roger Chartier, „Le monde comme représentation", Annales E.S.C., no 44/6, 1989, p. 15051520.

\section{CONRAD 1964}

Hermann Conrad, (ed.), Recht und Verfassung in der Zeit Maria Theresias. Die Vorträge zum Unterricht des Erzherzogs Josephs..., KölnOpladen 1964.

\section{DELON 1997}

Michel Delon (sous la direction de), Dictionnaire européen des Lumières, Paris 1997.

\section{DIXON ET AL. 2009}

Scott S. Dixon, Dagmar Freist, Mark Greengrass

18 Sellmann, Matthias, Religion und soziale Ordnung. Gesellschaftstheoretische Analysen, Campus Verlag, Frankfurt/New York 2007. 
(ed.), Living with Religious Diversity in EarlyModern Europe, Ashgate, 2009.

\section{DO PACQ ET AL. 2010}

David Do Pacq; Mathilde Monge; Laurent Tatarenko (sous la direction de), Des religions dans la ville. Rapports et stratégies de coexistence dans l'Europe des XVIe - XVIIle siècles, Presses universitaires de Rennes, 2010.

\section{HIŠAM $1989^{2}$}

Džait Hišam, Evropa i islam, Sarajevo 1989².

\section{ENCYCLOPÉDIE 1751-1772}

Encyclopédie ou Dictionnaire raisonné des sciences, des arts et des métiers, Paris 1751-1772. Vidjeti natuknice: Tolérance, Intolérance, Conscience, Hérétiques, Persécuteurs..., Théocratie, Prêtres, Superstition...

\section{ERLEWINE 2010}

Robert Erlewine, Monotheism and Tolerance. Recovering a Religion of Reason, Indiana University Press, 2010.

\section{FRANK 1979}

Isnard Frank, „Zum spätmittelalterlichen und josephinischen Kirchenversändnis", u: E. Kovacs (ed.), Katholische Aufklärung und Josephinismus, Wien 1979.

\section{GRLIĆ $1982^{2}$}

Danko Grlić, Leksikon filozofa, Zagreb 1982 ².

\section{HUDAL 1922}

Alois Hudal, A., Die serbisch-orthodoxe Nationalkirche, Graz 1922.

\section{IGGERS 1983}

Georg G. Iggers: The German Conception of History: The National Tradition of Historical Thought from Herder to the Present, 2nd rev. edn., Wesleyan University Press, Middletown, Ct., 1983.

\section{JEFFERSON 1984}

Thomas Jefferson, Writings, The Library of America, 1984.

\section{KAMEN 1967}

Henry Kamen, Intoleranz und Toleranz zwischen Reformation und Aufklärung, Wien 1967.

\section{KARNIEL 1986}

Josef Karniel, Die Toleranzpolitik Kaiser Josephs II., Bleicher Verlag 1986.

\section{KOTJE ET AL. 1970-1974}

Raymund Kottje, Bernd Moeller, (ed.), Ökumenische Kirchengeschichte, 3 Bde., C. Kaiser, Mainz, 1970-1974.

\section{LAURENS ET AL. 2009}

Henri Laurens, John Tolan, Gilles Venstejn, L'Islam et l'Europe, des origines à nos jours, Odile Jacob, 2009.

\section{LONGENECKER 1994}

Stephen L. Longenecker, Piety and Tolerance. Pennsylvania German Religion, 1700-1850, The Scareerow Press, Inc., Metuchen, N.J. \& London, 1994.

\section{LÖW 2001}

Martina Löw, Raumsoziologie, Suhrkamp 2001.

\section{LUTZ 1977}

Heinrich Lutz (Hg.), Zur Geschichte der Toleranz und Religionsfreiheit, Darmstadt 1977.

\section{MAASS 1953}

Ferdinad Maaß, Der Josephinismus. Quellen zu seiner Geschichte in Österreich 1760-1790, Bd. 2 (Fontes Rerum Austriacarum), Wien 1953.

\section{MITROFANOV 1910}

Paul von Mitrofanov, Joseph II. Seine politische und kulturelle Tätigkeit, translated from Russian by V. Demelič with an introduction by Dr. Hanns Schlitter, Wien 1910.

\section{MITSCHERLICH 1974}

Alexander Mitscherlich, „Toleranz - Überprüfung eines Begriffs", Wien 1974.

\section{NEWMAN 1982}

Jay Newman, Foundations of Religious Tolerance, University of Toronto Press, 1982.

\section{O'BRIEN 1969}

Charles H. O'Brien, „Ideas of Religious Toleration at the Time of Joseph II. A Study of the Enlightenment among Catholics in Austria", Transactions of the American Philosophical Society, N.S. 59, Part 7, Philadelphia 1969. 


\section{PATZER 1981}

Franz Patzer, (Hg.), Kaiser Joseph II. und die Toleranz: 200 Jahre Toleranzpatent 1781 - 1981, Rathaus, Wien 1981.

\section{POPKIN 2003}

Richard Popkin, The History of Scepticism from Savanarola to Bayle, Third, enlarged, edition, 2003.

\section{RENDTORFF 1982}

Trutz Rendtorff, (Hg.), Glaube und Toleranz. Das theologische Erbe der Aufklärung, Gütersloher Verlagshaus Ged Mohr 1982.

\section{ROSTWOROWSKI 1990}

Emmanuel Rostworowski, „The Polish Commonwealth in the 18th Century Europe", u: Nation - Church - Culture. Essays on Polish History, Catholic University of Lublin, 1990, str. 69-89.

\section{ROUSSEAU 1993}

Jean-Jacques Rousseau, Politički spisi, Informator i Fakultet političkih znanosti, Zagreb 1993.

\section{ROUSSEL 1998}

B. Roussel, B., M. Grandjean, (ed.), Coexister dans l'intolérance: l'Édit de Nantes (1598), Labor et Fides, Genève 1998.

\section{RUFFINI 1901}

Francesco Ruffini, La libertà religiosa. Storia dell'idea, Bocca, Torino 1901.

\section{SINA 1991}

Mario Sina (a cura di), La tolleranza religiosa. Indagini storiche e reflessioni filosofiche, Vita e pensiero. Pubblicazioni dell'Università Cattolica del sacro Cuore, Milano 1991.

\section{SAGARRA 1977}

Eda Sagarra, A Social History of Germany, 1648 - 1914, New York: Holmes \& Meier, 1977.

\section{SAHLINS 1998}

M. D. Sahlins, Au coeur des sociétés: raison utilitaire et raison culturelle, Gallimard, Paris 1998.

\section{SALIGMAN 2004}

Adam B. Seligman, Modest Claims. Dialogues and Essays on Tolerance and Tradition, University of Notre Dame Press, 2004.

\section{SELLMANN 2007}

Matthias Sellmann, Religion und soziale Ordnung. Gesellschaftstheoretische Analysen, Campus Verlag, Frankfurt/New York 2007.

\section{VERNON 2010}

Richard Vernon, (ed.), Locke on Toleration, Cambridge University Press, 2010.

\section{VOLTAIRE 1988}

Voltaire, Rasprava o toleranciji. Povodom smrti Jeana Calasa (1763), Školske novine, Zagreb 1988.

\section{VOLTAIRE 2009}

Volter, Filozofski rečnik, Edicija, Beograd 2009.

\section{VOLTAIRE 1878}

Voltaire, „Essai sur les moeurs et l'esprit des nations", Oeuvres complètes, XI, Garnier, Paris 1878.

\section{WALKER 1971}

Mark Walker, German Home Towns: Community, State, and General Estates, 1648 - 1871, Ithaca \& London: Cornell University Press, 1971. 


\section{SAŽETAK}

Vjerska trpeljivost u Habsburškoj Monarhiji u 18. stoljeću, točnije u reformskom razdoblju u drugoj polovici vijeka, dijeljeno je iskustvo epohe europske Prosvijećenosti. Utemeljena je u kritičkom propitivanju različitih shvaćanja trpeljivosti u rasponu od Voltairea i Rousseaua do Febroniusa i Muratorija. Njezina su povijesna izvorišta dublja. Monoteistički eklezijalni i monarhijski univerzalizam od 15. do 17. stoljeća iscrpljuju se u dugotrajnim cikličkim konfliktima s više europskih epicentara pa u 18. stoljeću ključnim postaje pitanje kako konfesionalne aspekte trpeljivosti povezati sa sekularnim imperativima slobode savjesti. S vremenom je vjerska trpeljivost za prosvjetitelje sve manje interkonfesionalni, a sve više intrakonfesionalni problem s etičkim i političkim implikacijama. Za prosvijećene apsolutiste, poput Habsburgovaca u to doba, bitni su njezini sekularni aspekti. Ključno je pitanje kako osigurati mir i boljitak u društvu. Radilo se o tome da se religiju svede na "društvenu činjenicu“ (un fait social), podložnu načelu korisnosti ili na superstrukturu koja legitimira i reprezentira materijalne interese društva. $U$ oba je slučaja religijska tolerancija postajala i sekularni fenomen.

\section{SUMMARY}

\section{"Enlightened" Modernization and Tolerance in Habsburg Monarchy in the $18^{\text {th }}$ Century: Problems of Approach - Conflicting Concepts and Contradictory Practices}

Religious toleration in the Habsburg Monarchy in the $18^{\text {th }}$ century - more precisely, in the period of dynastic reforms taking place in the second half of the century - comes out from different traditions within the Habsburg realm, as well as from other European sources. It reflects controversial aspirations within the Habsburg empire facing challenges of the European Enlightenment. The article is focused upon distinctive notions of religious toleration, including references to Voltaire and Rousseau, as well as to Febronius and Muratori, who used to determine mostly attitudes towards it in the Habsburg Monarchy. It has been done by making references to changes of Habsburg practices of toleration between the $15^{\text {th }}$ and $17^{\text {th }}$ centuries. In the $18^{\text {th }}$ century as the key question emerges the interrelationship between limits of the post-Tridentine Roman Catholic confessional toleration and challenges of the Habsburg Monarchy based on freedom of consciousness of its subjects. The essential dynastic concern is how to make social stability and prospertity possible.

Keywords: Habsburg Monarchy, Habsburgs, $18^{\text {th }}$ century, enligthement, cameralism, religious tolerance 